\title{
The Prevention of Ageing in the French Political Agenda: The Role of Sports and Physical Activities
}

\author{
By Cécile Collinet ${ }^{*}$ \\ Pierre-Olaf Schut ${ }^{\dagger}$ \\ Jérémy Pierre
}

The first phase of a public policy consists in placing a public issue on the political "agenda". To examine this policy, classical analyses of political agendas underline the operating factors in action when a question comes to be viewed as a public issue. Here we shall consider French policies related to the prevention of ageing through sports and physical activities (APS). More specifically, we shall analyse three factors which gave this issue such power as to raise questions to the public authorities. The first factor regards demographic, social and economic changes combined with new ways of apprehending the elderly and the body, but also changes related to the French health policy and its definite direction towards prevention. Indeed life expectancy is steadily getting longer which makes the financing of retirement pensions more complex - all the more so as health expenses increase with age. The second factor is the existence of a corpus of knowledge regarding physical and sports activities as well as ageing. This combination forms an "epistemic community" carried by the medical profession. As a matter of fact, the recommendations and expert-assessments related to the role of physical activities to support "ageing well" build their legitimacy on a set of multidisciplinary bodies of knowledge within the sphere of gerontology. The third major factor concerns actions undertaken by international institutions like the UNO or the WHO which gave the necessary incentive to indirectly lead the French government action. Since the 1970s, old age - or "the third age" as it is called in France - has progressively become a crucial element in international policies. In France, it is conveyed through the notion of wellaging which can be found at the heart of many action plans.

\section{Introduction}

Classical analyses of the political agenda, like those carried out by Cobb and Elder (1983) and Cobb, Ross and Ross (1976), underline the various factors involved in the consideration of a problem within the framework of public policies. Besides, the analysis of public policies in terms of ideas,

\footnotetext{
* Professor, Université Paris-Est, Marne-la-Vallée, France.

${ }^{\dagger}$ Lecturer, Université Paris-Est, Marne-la-Vallée, France.

‡Lecturer, Université Paris-Est, Marne-la-Vallée, France.
} 
institutions and interests (the three "I"s) by Palier and Surel (2005) leads us to reflect on the plurality of factors operating when considering an issue as a public problem.

In this contribution, we shall concentrate on the policies relative to the prevention of ageing and, more specifically, to the role played by sports and physical activities (APS) in this field.

In France, ageing policies started taking shape with the Laroque report drawn up in 1962 and stemming from the Commission of Studies on Ageing Issues. After a relatively long latent period, measures accelerated in the 2000s, just when issues related to an ageing population were looming: would the National Health Service take charge of dependency? From then on, four mainstays were called up to prevent ageing: nutrition, social activity, cognitive stimulation and APS. In 2006, the latter appeared as a major point in the program of the National Institute for Health Prevention and Education: "Eat well, move well... and live fit! Guidelines for the elderly". The practice of APS also constituted the third axis of the Well-Ageing program in 2007.

Our contribution shows that the inclusion of APS into the French public policies required the presence of three complementary conditions:

- demographic, social and economic transformations coupled with modifications in the representation of the elderly and the body, but also adjustments in the French health policy and its increasing emphasis on prevention;

- the existence of a corpus of knowledge regarding APS and ageing, constituting an epistemic community carried by the medical profession;

- incentive coming from international institutions like the UNO (cf. the Vienna plan in 1982) or the WHO (cf. the Active Ageing program in 2002) which indirectly orientated the French government's action.

\section{Demographic, Social and Cultural Transformations}

The development of public policies related to the prevention of ageing was brought to the foreground with the gradual apparition of a new social issue justifying State intervention. According to Kingdon (2002), a policy window opens with the conjunction of three streams: the emergence of problems, the definition of public policies and the politician's decision time. We shall first highlight how an issue emerged from specific demographic circumstances. Bossy (2010) reminds us that identifying a problem may take time, but it is important to first apprehend the various elements which are concurrently at stakes.

Indeed, the issues relative to an ageing population raise several successive questionings and their conjunction emphasizes the degree of the politicians' consideration of old age. The issues are of different kinds: first, a longer 
lifespan means that the working life is followed by a gradually extending retirement period. The contributory pension scheme set up in France during the Second World War and integrated into Social Security (the French public welfare system) after the war, prepares the foundations for financing the workers' pensions, thus enabling them "to finish their lives with dignity". At that time, life expectancy for men was below 60 years, but all along the second half of the $20^{\text {th }}$ century, the potential life span continued to extend regularly. At first, this concerned the whole population of whatever age, due to the lessening of infectious mortality. Then, at the end of the $20^{\text {th }}$ century, this tendency was strengthened by a lower mortality rate with the elderly, due in particular to the diminution of mortality related to cardiovascular diseases (Prioux, 2006; Meslé, 2006). Today the men's lifespan has reached almost 80 years and the women's 85 years. Consequently financing retirement pensions has become a serious economic issue.

The very existence of a pension scheme is a public concern and it soon turns into a problem in as much as the extended lifespan is combined with a distinctive point in the age pyramid: the ageing of the whole baby-boom generation. The "grandpa-boom" compromises the public retirement system based on a contributory pension scheme. The proportion of people in employment is reduced whereas a whole generation of retiring people is coming up. Although this problem was soon depicted (Vernière 1990a, 1990b), its very complexity and temporality incited the successive governments to take phased measures ${ }^{2}$ without actually overthrowing the old system and setting up a new viable one which would have taken demographic forecasts into consideration.

The ageing issue holds another important aspect related to medical care and especially to its cost, since the public welfare system ensures the financing of a major part of French people's health expenses. Statistics reveal that health expenses increase with age. An extended lifespan combined with an ageaing population represents a potential risk to multiply health expenditures (Albouy $\&$ al. 2009), despite the number of studies which have questioned the linearity of this connection (Grignon, 2002; Dormont, 2009). Indeed, depending on the state of health of the elderly at various stages of their lives, and on the cost inherent to death (the last year of life representing quite a large portion of older people's health expenses), the increase in health public expenditures could be contained by an increase in riches. Then prevention policies to preserve people's health would play an essential role to aim at the scenario that would be most beneficial to public finances.

Planning health preservation also presumes a change in the representations of the elderly and their bodies. These representations were revolutionized in the

\footnotetext{
${ }^{1}$ The Resistance National Council : Programme du Conseil National de la Résistance, March $15,1944$.

${ }^{2}$ Various reforms progressively lengthen the duration of contribution paying, postpone retirement age and reduce inequalities between workers (the Balladur reform in 1993; creation of a reservation Fund for pensions in 1999; the Fillon reform in 2003; reform of special pension systems in 2007; the Woerth reform in 2010).
} 
late $20^{\text {th }}$ century. Bourdelais (1997) depicts the many aspects of old age. The age of body deterioration is pushed back and there appears a new life phase with specific characteristics: freedom from professional activities and the physical ability to fully enjoy it. The "third age" concept emerged from this basis in the 1970s (Caradec, 2010), putting off to a "fourth age" the time of health troubles. The public action resulting from the propositions made in the 1962 Laroque Report, comes within the scope of this determination to turn retirement into a time for self-fulfillment achieved through better social integration (Guillemard, 1980). Besides enjoying their full physical capacities, retired people also wish to "grow old young" (Gestin, 2001). Thus, when R. Feillet (2000) studies the preoccupations of ageing people, it is not surprising to find that right after the desire to "ease pain" their concerns are related to wrinkles, weight and most of all fitness.

Consequently practising physical activities becomes quite significant to benefit senior citizens. Gymnastics and sports, long-standing approaches to physical education for the youth at school, now appear like relevant solutions for seniors. Clubs for retired people proliferated in the 1970s. They frequently offer gym sessions to elderly people who were not immersed in the sports culture as youngsters, especially factory workers and farmers living in rural areas (Feillet \& Vigarello, 1996). In other social circles, practising in sports associations appears like the best way to offset ageing (Feillet, 2000) for two reasons: the social links thus created with the younger generations and the physical activity itself. This commitment to physical practices is all the more sensible as the knowledge regarding the benefits of such activities for the health of elder people is increasing.

\section{The Existence of a Corpus of Knowledge Regarding APS and Ageing}

The fact that public policies took APS into consideration as a tool for the prevention of ageing is also the consequence of the structuring of a specific espitemic community concerned with these themes. Indeed, the present ministerial expert-assessments and recommendations (INSERM, 2008 and the Well-Ageing ministerial program, 2007-2009) draw the legitimacy of their advice, measures and/or scenarios, from a corpus of knowledge carried by the medical profession. Gerontology, for example, which is concerned with ageing, comprises a set of scientific fields which includes physical activities. Hence APS constitute a means to fight off ageing and gain health.

Far from confining themselves to the physical dimension related to the notion of health, these various expert-assessments also place psychological and social dimensions at the centre of their recommendations - following the definition of health given by the $\mathrm{WHO}^{1}$ - thus contributing to broadening the field of knowledge.

These expert-assessments are at the heart of contemporary public policies (Robert, 2008) because they suggest solutions for the problems in question and

\footnotetext{
${ }^{1}$ The WHO defines health as « a state of complete physical, mental and social well-being ».
} 
indirectly participate in the decision-making process. Resorting to an expertassessment is meant to be a neutral and objective approach which offers legitimacy to the political decisions thus based on well-grounded reasons. This "legitimacy transfer" (Leclerc, 2001) rests in particular on the fact that "the expert can link his assessment to an authenticated knowledgeable corpus" (Trépos, 1996, p.68). But historically, how was the "knowledgeable corpus" relative to the role of APS in fighting old age put together? How can physical activity contribute to the three dimensions included in the notion of health?

The structuring of the knowledge specifically related to physical activity for senior citizens is rooted in what we know about adults' health in general. Over a first phase, the knowledge gathered together came from exact sciences and only concerned the physical aspect of health. Before the 1980s, knowledge was centred on improving the cardio-respiratory system via highly intensive activities. From the mid-1990s, knowledge centred on lessening risks of chronic pathologies as a priority. Recommendations to this effect were made in the Surgeon General report (USDHHS, 1996) which specifies that "the latest recommendations advise people of all ages to accumulate 30 minutes or more of moderate physical activity (such as brisk walking) on most, if not all, days of the week. It is also admitted that, for most people greater health benefits can be gained through a more vigorous physical activity or longer periods of time". These measures were adopted by the WHO and later updated by Haskell \& coll. (2007). The latter recommended either moderate intensity aerobic activities for a minimum of 30 minutes five days a week, or vigorous intensity aerobic for a minimum of 20 minutes three days a week. Within this 2007 update, the physiological knowledge was also put to use for adults over 65 and adults over 50 suffering from chronic diseases. Even though the recommendations were similar, the report specifies that it is important for this type of population to individualize the practice and strengthen their muscles. Besides these recommendations, scientists and medical researchers have widely demonstrated the prophylactic effects of physical activity for senior citizens (Vogel, Brechat, Lepretre \& coll., 2009): it reduces the risk of developing certain types of cancer, overweight, insulin-dependent diabetes, cardiovascular diseases and osteoporosis.

Since the 1960s, the mental and psychological dimensions of physical activities have been a subject of research. In 1987, the National Institute of Mental Health underlined the wholesome effects of APS on mental health. Ten years later, Fox (1999) synthesized 53 articles demonstrating the positive impact of physical activity on individuals, not only on their psychological state, but also on their self-image. A few years later, these conclusions were reiterated (Penedo \& Dahn, 2005). In the 2000s an increasing quantity of information relative to these research themes was released. In an article on the positive effects of APS on the cognitive functions of ageing people, Audiffren, André and Albinet (2011) presented an inventory of the production of knowledge on these themes over the last twenty years, referring to epistemology studies - lengthways, crossways and interventional (Churchill, Galvez, Colcombe \& coll., 2002 ; Albinet, Fezzani, Thon ; 2008). The authors 
drew up a report on these positive effects, specifying that physical practice for senior citizens makes it possible to "preserve autonomy, slow down pathological and non-pathological brain ageing, reduce risks of developing neurological diseases, and improve their quality of life. They also underlined a triple advantage: clinical, economical and social.

The third field of knowledge is related to the social dimension of health for the elderly. An individual's quality of life is "a very wide concept influenced, in a complex way, by the person's physical health, his psychological state, how independent he can be, his social relationships, and how he relates to the main factors of his environment" (Nutbeam, 1999). Studies were carried out to grasp the degree of this "quality of life" with elder people (Clark \& coll., 1999). The conclusion is that people who practise a physical activity enjoy a better quality of life than sedentary people - these results are also true for adults from 18 to 64 years old (Brown \& Frankel, 1993 ; Melin \& coll., 2003). Yet research on the senior citizens' ways of life reveals a tendency to isolation (Findlay \& Robyn, 2003; Poisson-Goulais, 2005). So, besides having a positive impact on the physical and psychological health of the elderly, practising physical activities makes it possible to fight solitude through integrating a group, being appreciated by others, participating in social life and, more generally, creating a social network.

Nowadays, the positive outcomes for senior citizens practising physical activities are largely demonstrated by the various forms of knowledge above mentioned. As gerontology claims to be multidisciplinary, APS are undeniably a tool in its quest for "bio-psychological wellbeing" (WHOQOL Group, 1993). This corpus of knowledge represents anchor points for the various recommendations at the heart of the public policy on Active Ageing. Now how are the various levels of this public policy articulated? Are these recommendations included in the political agenda? To what extent are these expert-assessments followed up?

\section{Incentive Coming from International Institutions}

As underlined by Bossy (2010) in his study of public policies to fight obesity in France and Great-Britain, for a sanitary problem to appear on the political agenda, it is often the case that incentive coming from international institutions first initiates a consideration of the issue at the level of the various nations it represents. Regarding the ageing policy, this role was played by the United Nations Organization (UNO), the World Health Organization (WHO) and the European Community.

In the 1970s, the UNO instigated a genuine debate on the economic and social consequences of the ageing population phenomenon. In 1978, the General Assembly decided (resolution 33/52) to organize the first "senior citizen world assembly". Its purpose was to devise an international action plan to meet the needs and aspirations of senior citizens and to analyze the relationships between an ageing population and the countries' economic 
growth. The outcome of this meeting was the 1982 Vienna Plan approved by the 124 countries attending this first assembly. The plan defines three priority orientations: the sustainability of development in an ageing world; the promotion of health and well-being until old age; the creation of supportive and favourable environments for every age group. In 1991, the United Nations Principles for the Elderly were promulgated. After acknowledging how much senior citizens contribute to their own societies, this text offers the international community both a roadmap and an approach to issues related to ageing - the general purpose being to make the situation of the elderly a priority with national policies. Reflections on this topic multiplied until 1995 when the World Summit for Social Development was held in Copenhagen. Within the action framework of the "Copenhagen Program", a section dedicated to elderly people advocates offering this population more possibilities to improve their lives. Finally, in 2002, the Report on the second World Assembly on Ageing, in the continuity of the Vienna Plan, focuses on the formulation of an international action plan about ageing. Three similar priority orientations are suggested: the elderly and development; the promotion of health and wellbeing for the elderly; the creation of a favourable and supportive environment.

The issue related to ageing is clearly becoming a serious preoccupation for international organizations which found their investigations on various quantitative measures related to the demographic and economic changes in Western countries. The notion of health and well-being emerging from these plans and programs has been especially spread by the WHO. As early as 1986, this organization presented a study on the theme of Ageing and well-being: approaches to a multidimensional evaluation. But only in 2002 was a real action plan set up through the Active Ageing program which was presented as a contribution to the UNO Second World Assembly on Ageing (Madrid, 2002). It is a gathering of observations and recommendations formulated in favour of active and healthy ageing, along with practical suggestions which can be used as foundations to finalize more specific measures at local, regional, and national levels. In this text, recommendations regarding physical practices can be found. The idea is "to encourage the elderly to adopt or maintain an active and healthy way of life, particularly through physical and sports activities" (point 67.f). From then on, two mainstays for the prevention of ageing have been the subject of recurrent recommendations: nutrition and physical exercise. The concept of active ageing developed within the WHO, along with Guides of wholesome practices for senior citizens wishing to stay in good health. Thus in 2007, the Global Age-friendly Cities Guide developed this concept of Active Ageing. A series of reports and articles on this theme followed in succession, integrated into general health plans including the elderly - like the World recommendations on physical activity for health in 2012, encouraging people aged 65 and more to practise various physical activities. Besides, the WHO website shows works dedicated to physical activities practised by elderly people within the framework of a world strategy for nutrition, physical exercise and health (2012), insisting on the benefits thus gained by senior citizens. They can improve their cardiopulmonary endurance and the state of their muscles 
and bones, as well as reduce the risk of non-transmitted diseases, depression and cognitive deterioration. As mentioned above, some practical recommendations are also made in terms of intensity of effort and periodicity of practice.

This vast movement was relayed in 2003 by the European Union which launched the Healthy Ageing program as part of the UE public health program, and in 2009 by the OECD (Organization for Economic Cooperation and Development) with its Policies for Healthy Ageing (Oxley, 2009) which investigate policies relative to ageing in good health.

It is in this international context that France was going to develop its own ageing policy around the notion of well-ageing. At first, the role of physical activities, in particular for senior citizens, appeared within the context of politically-led campaigns for better nutrition and fight against obesity (First National Program for Nutrition and Health 2001-2005). As for texts related to an ageing policy in France, the first one dates back to 1962 (the Laroque Report), but then nothing was produced until 2005 when the Reference Book for healthy practices: preventing falls with elderly people living at home was released (INPES ${ }^{1}$, Bourdessol H., Pin S. (dir.), 2005). Again physical activities are viewed as a means to prevent ageing and especially dependence - a problem which has been preoccupying French health policies since the end of the 1990s (Ennuyer, 1998). From then on, a series of prevention programs followed one another like the INPES prevention project in 2006 - "Eat well, move well... and live fit! Guidelines for the elderly"- which promotes healthy eating and physical activities from the age of 55. But the most ambitious program is the Well-ageing National Plan (2007-2009) which suggests the steps to be followed for "successful ageing", from the perspective of individual health as well as social relationships, leaning on the organization and implementation of adapted preventive actions. Its third axis is dedicated to the promotion of sports and physical activities ${ }^{2}$, reinforced by the Well-Ageing Label Specifications: living together, in 2009. Evaluating the Well-Ageing Plan and its third axis makes it possible to draw a list of measures taken in favour of sports and physical practices: creation of the first directory of sports associations offering activities for senior citizens; increased support to sports federations opened to senior citizens; training of sports professionals; assessment of older people's physical aptitudes; improved communication through "open-doors days" for senior citizens in sports federations, etc.

As demonstrated, three elements are essential to the consideration of physical activities in French public policies for the prevention of ageing: the evolution of the wider economic and social context; establishing a field of knowledge and expertise; and incentive institutions taking things in their hands. Thus, the various streams defined by Kingdon (2002) are combining progressively: problems are being defined and becoming more and more

\footnotetext{
${ }^{1}$ INPES: the National Institute for Prevention and for Health Education

${ }^{2}$ The role APS play in health care is widely exposed by expert-assessments like the one made by INSERM (2008), for example, which was turned into a national plan - the National Prevention Plan through Sports and Physical Activities (PNAPS) - in 2008.
} 
inescapable. The incentive from international institutions prepares the ground for public policies. Then, the policy window being open, it is time for the politician to step in and the definition of a prevention policy through APS appears on the political agenda. As a result, physical activities take an everincreasing importance - next to nutrition - in the programs for prevention and for health promotion. The concept of nutrition is even extended over the two PNNSs $^{1}$ (National Plan for Nutrition and Health) and concerns the whole of the population since it is meant to point both to nutrition and to physical activities. Consequently physical activity becomes a crucial part of health and the fight against ageing. From this perspective, prevention means taking action as early as possible. Hence the PNAPS (National Plan for prevention through Sports and Physical Activities) envisions the practice of APS from a very early age through adolescence. Then the impact on health and ageing is seen as a continuum and anticipation.

Mobilizing local actors to actually carry out these programs remains an unsolved problem, as evidenced by the assessment of the Well-Ageing Plan which highlights the lack of financial means and dynamics in the projects tackled to stimulate associations offering APS as well as the public concerned. Including an issue in the political agenda does not guarantee a deep change in ways and practices. In this respect, the assessment of public policies is a major tool to improve their impact.

\section{References}

Albinet, C., K. Fezzani \& B. Thon (2008). 'Vieillissement, activité physique et cognition.' Science \& Motricité, $63: 9-36$.

Albouy, V., E. Bretin, N. Carnot \& M. Deprez (2009). 'Les dépenses de santé en France : déterminants et impact du vieillissement à l'horizon 2050.' Les Cahiers de la DGTPE 11 : 1-31.

Audiffren, M., N. André \& C. Albinet (2011). 'Effets positifs de l'exercice physique chronique sur les fonctions cognitives des séniors : bilan et perspectives.' Revue de neuropsychologie 3(4) : 207-225.

Robert, C. (2008). 'Chapitre 11 : Expertise et action publique.' In : O. Borraz \& V. Guiraudon (eds.), Politiques publiques 1, 309-335. Paris : Presses de Sciences Po.

Bossy, T. (2010). 'Les différentes temporalités du changement : la mise sur l'agenda de l'obésité en France et au Royaume-Uni.' In : B. Palier \& Y. Surel (eds.) Quand les politiques changent. Temporalités et niveaux de l'action publique, 145- 182. Paris : L'Harmattan.

Bourdelais, P. (1997). 'Les nouveaux visages du vieillissement de la population française.' Lien social et Politiques 38 : 11-20.

Brown, B.A. \& B.G. Frankel (1993). 'Activity through the years : leisure, leisure satisfaction and life satisfaction.' Sociology of Sport Journal 10: 1-17.

${ }^{1}$ First National Nutrition Health program: 2001-2005. Second National Nutrition Health program: 2006-2010. 
Caradec, V. (2010). Sociologie de la vieillesse et du vieillissement. $2^{\text {nd }}$ ed. Paris: Armand Colin.

Churchill, J.D., R. Galvez, S. Colcombe \& coll. (2002). 'Exercise, experience and the aging brain.' Neurobiol Aging 23: 941-955.

Clark, S., M.M. Long \& L.G. Schiffman (1999). 'The mind body connection: the relationship among physical activity level, life satisfaction, and cognitive age among mature females.' Journal of Social Behavior and Personnality 14: 221241.

Cobb, R.W. \& C.D. Elder (1983). Participation in American Politics : The Dynamics of Agenda Building. $2^{\text {nd }}$ ed.. Baltimore: Johns Hopkins University Press.

Cobb, R.W., J.-K. Ross \& M.H. Ross (1976). 'Agenda Building as a Comparative Political Process.' American Political Science Review 70(1): 126-138.

Commission d'étude des problèmes de la vieillesse (présidée par P. Laroque). (1962). Politique Vieillesse.

Dormont, B. (2009). Les Dépenses de santé. Une augmentation salutaire?. Paris : Editions Rue d'Ulm/Presses de l'Ecole Normale Supérieure.

Ennuyer, B. (1998). 'La construction du champ de la vieillesse dépendante 1973 1987 : le retour en force du modèle de vieillesse biomédicale.' Revue Prévenir $35: 63-70$.

Feillet, R. (2000). Pratiques sportives et résistances au vieillissement. Paris: L'Harmattan.

Feillet, R. (1996). Représentations du vieillissement et attitudes des retraités et des jeunes en situation de confrontation sur le terrain sportif. Ph.D. diss., Paris V University.

Findlay, R. A. (2003). 'Interventions to reduce social isolation amongst older people: where is the evidence?' Ageing \& Society 23: 647-658.

Fox, K.R. (1999). 'The influence of physical activity on mental well-being.' Public Health Nutr, 2: 411-418.

Gestin, A. (2001). 'Un nouvel impératif pour les hommes et les femmes retraités: vieillir-jeune' Cahiers du genre 31(2) : 203-219.

Grignon, M. (2002). 'Impact macro-économique du vieillissement de la population sur les dépenses d'assurance maladie en France.' Santé société et solidarité 2002(2) : $135-154$.

Guillemard, A.-M. (1980). La vieillesse et l'Etat. Paris : Presses Universitaires de France.

Haskell, W.L., I.M. Lee, R.R. Pate, K.E. Powell, S.N. Blair \& coll. (2007). 'Physical activity and public health: updated recommendation for adults from the American College of Sports Medicine and the American Heart Association' Circulation 116: 1081-1093.

INSERM (2008). Activité physique. Contextes et effets sur la santé. Synthèse et recommandations. Paris : INSERM.

Institut National de Prévention et d'Éducation pour la Santé (2006). Manger, bouger... et vivre en forme! Des guides pour les personnes âgées. Paris : INPES.

Bourdessol, H. \& S. Pin (eds.) (2005). Référentiel de bonnes pratiques : Prévention des chutes chez les personnes âgées à domicile. Paris : INPES.

Kingdon, J. (2002). Agendas, alternatives, and public policies. $2^{\text {nd }}$ ed. London: Longman.

Leclerc, G. (2001). 'Histoire de la vérité et généalogie de l'autorité.' Cahiers internationaux de sociologie 111 : 205-231. 
Melin, R., F. Fug-Meyer \& A.R. Fug-Meyer (2003). 'Life satisfaction in 18 to 64 year-old Swedes: in relation to education, employment situation, health and physical activity' Journal of Rehabilitation Medecine 35: 34-90.

Meslé, F. (2006). 'Progrès récents de l'espérance de vie en France. Les hommes comblent une partie de leur retard.' Population 61/4 : 437-462.

Ministère de l'emploi et des solidarités. Ministère délégué à la santé. (2001). Programme National Nutrition-Santé 2001-2005.

Ministère de la Santé et des Solidarités, Ministère délégué à la Sécurité Sociale, aux Personnes âgées, aux Personnes handicapées et à la Famille, Ministère de la Jeunesse, des Sports et de la Vie associative (2007). Plan National «Bien Vieillir $\gg(2007-2009)$.

Ministère de la santé, de la jeunesse, des sports, Ministère du travail, des relations sociales, de la famille et de la solidarité et de la ville (2009). Cahier des charges label Bien Vieillir : Vivre ensemble.

Ministère de la santé, de la jeunesse, des sports et de la vie associative (2008). Plan National de prévention par l'Activité Physique et Sportive (PNAPS) : Retrouver sa liberté de mouvement.

Nutbeam, D. (1999). Glossaire de la promotion de la santé. Copenhague : Organisation mondiale de la santé, Bureau régional de l'Europe.

Organisation des Nations Unies (1991). Principe des Nations Unies pour les personnes âgées. New-York: ONU.

Organisation des Nations Unies (1995). Sommet Mondial pour le Développement Social, Copenhague, 6-12 mars 1995. New-York: ONU.

Organisation des Nations Unies (2002). Rapport de la deuxième Assemblée mondiale sur le vieilliessement, Madrid 8-12 avril 2002. New-York: ONU.

Organisation Mondiale de la Santé (1986). 'Troisième âge et bien-être : approches d'une évaluation multidimensionnelle.' OMS, Publication offset 84. Genève : Organisation mondiale de la Santé.

Organisation Mondiale de la Santé (2002). Active Ageing, Vieillir en restant actif: Cadre d'orientation. Genève : Organisation mondiale de la Santé.

Organisation Mondiale de la Santé. (2004). Stratégie mondiale pour l'alimentation, l'exercice physique et la santé. Genève : Organisation mondiale de la Santé.

Organisation Mondiale de la Santé. (2007). Guide mondial des villes amies des ainés. Genève : Organisation mondiale de la Santé.

Oxley, H. (2009). 'Policies for Healthy Ageing : An Overview.' OECD Health Working Papers 42.

Palier, B. \& Y. Surel (2005). 'Les “trois I" et l'analyse de l'Etat en action.' Revue française de sciences politique 55(1) : 7-32.

Penedo, F.J. \& J.R. Dahn (2005). 'Exercise and well-being: A review of mental and physical health benefits associated with physical activity' Curr Opin Psychiatr 18: 189-193.

Poisson-Goulais, A. (2005). 'Relation entre lien social et dépendance de la personne âgée », in Aïn J., « Dépendances. Paradoxes de notre société ?' ERES : 143-162.

Prioux, F. (2006). 'L'évolution démographique récente en France' Population 61(4) : 393-435.

Trépos, J.-Y. (1996). La Sociologie de l'expertise. Paris : Presses Universitaires de France.

US Department of Health and Human Services (USDHHS) (1996). Physical Activity and Health: A Report of the Surgeon General. Atlanta, GA : US. Department of Health and Human Services, Centers for Disease Control and Prevention, National Center for Chronic Disease Prevention and Health Promotion. 
Vol. 1, No. 1 Collinet et al: The Prevention of Ageing ...

Vernière, L. (1990). 'Les retraites pourront-elles être financées après l'an 2000 ?'. In: Economie et statistique, $233: 19-27$.

Vernière, L. (1990). 'Retraites : l'urgence d'une réforme' Economie et statistique 233: 29-38. Vogel T., P.H. Brechat, P.M. Lepretre \& coll., (2009). 'Health benefits of physical activity in older patients: a review' Int J Clin Pract, 63, 303-320.

WHOQOL Group (1993). 'Study protocol for the world health organisation project to develop a quality of life assessment instrument' Quality of Life Research 2: 153159. 